\title{
Efektivitas dan Uji Kelayakan Bahan Ajar Tenis Lapangan Berbasis Multimedia Interaktif
}

\author{
Septian Raibowo ${ }^{1}$, Sapto Adi $^{1}$, Imam Hariadi ${ }^{1}$ \\ ${ }^{1}$ Pendidikan Olahraga-Universitas Negeri Malang
}

\section{INFO ARTIKEL \\ Riwayat Artikel: \\ Diterima: 10-09-2019 \\ Disetujui: 17-07-2020}

\author{
Kata kunci: \\ effectiveness; \\ teaching materials; \\ tennis; \\ interactive multimedia; \\ efektivitas; \\ bahan ajar; \\ tenis lapangan; \\ multimedia interaktif
}

\section{Alamat Korespondensi:}

\section{Septian Raibowo}

Pendidikan Olahraga

Universitas Negeri Malang

Jalan Semarang 5 Malang

E-mail: septianraibowo@unib.ac.id

\begin{abstract}
ABSTRAK
Abstract: This research aims to find out the effectiveness of interactive multimediabased tennis teaching materials for students. This research is a research on the development of interactive multimedia-based tennis teaching materials. The data was collected by distribution of questionnaires then next was analyzed with descriptive statistic technique. The research result shows that the interactive multimedia-based tennis teachingmaterials is effective and efficient to improve the learning outcomes and it has significant attractiveness.
\end{abstract}

\begin{abstract}
Abstrak: Penelitian ini bertujuan untuk mengetahui efektivitas bahan ajar tenis lapangan berbasis multimedia interaktif untuk mahasiswa. Penelitian ini merupakan penelitian pengembangan bahan ajar tenis lapangan berbasis multimedia interaktif. Data dikumpulkan dengan penyebaran angket dan kuisioner serta tes selanjutnya dianalisis dengan teknik statistik deskriptif. Hasil penelitian menunjukkan bahwa bahan ajar tenis lapangan berbasis multimedia interaktif efektif meningkatkan hasil belajar dan efisien serta memiliki daya tarik yang signifikan.
\end{abstract}

Tenis lapangan merupakan cabang olahraga yang populer di dunia. Tenis lapangan dapat dimainkan oleh semua orang tanpa batasan usia maupun jenis kelamin. Olahraga ini dapat dimainkan secara tunggal (single) ataupun ganda (double). Di Benua Asia, menunjukan bahwa tenis lapangan menempati urutan kelima dibawah sepakbola, badminton, renang dan bolabasket (Hakuhodo, 2012). Kemudian di Amerika Serikat, tenis termasuk kedalam top five olahraga yang sering dilakukan dilakukan dengan bolabasket di peringkat pertama (NPR et al., 2015). Tentu saja hal ini sudah cukup menggambarkan eksistensi tenis lapangan banyak digemari masyarakat di dunia disamping juga untuk prestasi juga bermanfaat untuk kebugaran tubuh. Tenis lapangan memberikan kontribusi yang cukup signifikan dalam hal kesehatan dan kebugaran tubuh seseorang. Orang yang berpartisipasi dalam olahraga tenis secara teratur sangat bermanfaat, termasuk kebugaran aerobik yang lebih baik, tubuh yang lebih ramping, peningkatan kesehatan tulang dan penurunan risiko terserang penyakit. Intensitas latihan saat bermain tenis secara teratur akan berkontribusi pada tingkat kebugaran yang lebih baik (Pluim et al., 2007).

Kemajuan ilmu pengetahuan dan teknologi yang sangat pesat dan bersifat global dewasa ini "memaksa" penyelenggara pendidikan tinggi meningkatkan kualitas pendidikan dan pembelajarannya secara terus-menerus untuk menghasilkan lulusan yang berkualitas. Perguruan tinggi dituntut selalu tanggap terhadap perubahan yang terjadi dalam segala aspek kehidupan. Sebagai agen perubahan (agent of changes), perguruan tinggi harus selalu siap berubah, baik dari sisi, manajemen, organisasi maupun substansi isi program akademiknya. Kualitas pembelajaran yang dilaksanakan di perguruan tinggi sangat berpengaruh terhadap kualitas pendidikan yang dihasilkan. Dosen yang mampu memfasilitasi proses belajar, kurikulum yang relevan, bahan ajar yang mampu menyediakan aneka stimulus, suasana yang menyenangkan, menarik, menantang, dan bermakna sangat dibutuhkan untuk mencapai sebuah pembelajaran yang berkualitas. Kualitas pembelajaran yang tinggi sangat mendukung tercapainya kompetensi yang diharapkan.

Pembelajaran adalah proses interaksi peserta didik dengan pendidik pada suatu lingkungan belajar dengan sumber belajar. Pembelajaran merupakan sebuah proses yang diberikan pendidik agar mendapat suatu ilmu pengetahuan, keterampilan, dan sikap kepada peserta didik (Komara, 2014). Pembelajaran saat ini memandang bahwa pembelajaran merupakan suatu proses yang yang melibatkan peserta didik dengan sumber belajar. Peran pembelajaran adalah menantang pendidik untuk menggabungkan teknologi pendidikan secara efektif dan efisien ke dalam proses pembelajaran, namun pada dasarnya untuk memfokuskan kembali filosofi pengajaran mereka dapat menerapkan pendekatan baru untuk pengajaran mengikuti perkembangan teknologi dalam pendidikan saat ini (Juniu, 2011).

Teknologi dengan pendidikan merupakan dua aspek yang tidak dapat dipisahkan. Teknologi merupakan bagian dari 
pendidikan yang dapat membantu pemecahan masalah dengan tujuan meningkatkan kualitas pendidikan. Teknologi telah masuk ke dalam kehidupan manusia dan masyarakat yang menjadikan aspek penting untuk kelangsungan hidup sehari-hari baik itu kehidupan sosial, pendidikan, profesional, dan kehidupan agamanya (Xavier \& Francis, 2017). Teknologi pembelajaran memiliki potensi untuk memberikan sejumlah peluang pembelajaran bagi siswa dan memperluas fungsi kognitif (Nurdyansyah \& Fahyuni, 2016). Dengan demikian, semakin mengikuti perkembangan zaman, sebuah teknologi memang sangat dibutuhkan untuk lebih memajukan dunia pendidikan dalam hal ilmu pengetahuan dan teknologi (IPTEK).

Salah satu unsur yang mempunyai banyak pengaruh dalam mempermudah mencapai tujuan pembelajaran adalah melalui media pembelajaran. Media pembelajaran diartikan sebagai segala sesuatu yang dapat digunakan untuk merangsang pikiran, perasaan, perhatian, dan kemauan sehingga dapat mendorong terjadinya proses belajar pada diri peserta didik. Selain itu, media digunakan sebagai sarana penyalur pesan dari sumber kepada penerima pesan, sehingga pembelajaran dapat mencapai tujuan yang diinginkan secara optimal. Penggunaan media pembelajaran akan membua kegiatan pembelajaran berjalan lebih menarik karena membuat peserta didik penasaran dengan materi apa yang tersaji dalam media tersebut. Pemanfaatan media pembelajaran dalam proses pembelajaran dapat membangkitkan keinginan, minat, dan motivasi serta membawa pengaruh baik terhadap psikologis peserta didik. Media pembelajaran mencakup semua materi dan sumber daya substansial yang bisa digunakan pendidik untuk menerapkan metode belajar dan memudahkan pencapaian tujuan pembelajaran (Dwiyogo, 2014). Pernyataan tersebut mengindikasikan bahwa memanfaatkan media dalam proses pembelajaran dapat membangkitkan minat, motivasi dalam mengikuti proses pembelajaran. Pemanfaatan media dalam pengajaran dapat memberikan akses pada gagasan baru seperti cara belajar, cara mengakses informasi yang sulit ditemukan, klarifikasi istilah atau konsep yang sulit dan bagaimana menyajikan informasi dengan menggunakan media pembelajaran yang berbeda.

Dalam hal proses pembelajaran pendidikan jasmani Asosiasi Nasional Olahraga dan Pendidikan Jasmani (NASPE, 2007) merekomendasikan (1) penerapan teknologi dalam pendidikan jasmani membantu siswa untuk pelajari tahapan gerak dengan baik, (2) pendekatan teknologi merupakan respons terhadap perubahan paradigma belajar menjadikan siswa sebagai pusat pembelajaran dan guru sebagai fasilitator. Kemudian menurut (Kavita et al., 2013) dalam penelitiannya penggunaan teknologi komputer dalam pengajaran pendidikan jasmani dapat meningkatkan minat dan motivasi siswa dalam berolahraga dibandingkan pengajaran pendidikan jasmani dengan penggunaan metode tradisional, sedangkan (Dwikat et al., 2018) penggunaan sistem multimedia memberikan kemudahan dalam pemahaman dan mendapatkan hasil yang terbaik dalam mempelajari teknik dan taktik dalam peningkatan hasil belajar pendidikan jasmani. Dengan memanfaatkan perangkat teknologi, visualisasi bahan ajar akan semakin menarik karena bermuatan konten multimedia (teks, grafik, gambar, animasi, suara dan video). Pemanfaatan penggunaan multimedia dalam bahan ajar ini terbukti lebih meningkatkan hasil pembelajaran. Hasil penelitian (Teoh \& Neo, 2007) menunjukan bahwa "fleksibilitas dalam multimedia dapat menggantikan petunjuk tekstual tradisional yang akan memungkinkan jangkauan yang lebih luas dari rangsangan, baik dalam lisan dan visual sehingga meningkatkan keterlibatan siswa dalam keadaan belajar".

Perkuliahan tenis lapangan ini memiliki tingkat kesulitan yang bervariasi. Oleh karena itu, pola pembelajaran harus bervariasi menyesuaikan dengan materi pembelajaran tersebut. Perkuliahan lebih bersifat ke praktik dan dituntut untuk menguasai keterampilan (psikomotor), sedangkan aspek pengetahuan (kognitif) dan sikap (afektif) mempunyai porsi yang sangat sedikit. Kemudian belum adanya bahan ajar tenis lapangan yang terintegrasi dengan pemanfaatan teknologi, sampai saat ini bahan ajar hanya berupa bahan ajar cetak sehingga mahasiswa banyak yang merasa cepat bosan dan sulit untuk memahami penjelasan dari dosen yang hanya mengandalkan buku saja. Bahan ajar yang digunakan bersifat pasif karena jika muncul kesulitan mahasiswa harus menunggu pada pertemuan berikutnya. Kemudian rata-rata mahasiswa tidak memiliki pengetahuan awal yang baik terkait tenis lapangan, mahasiswa baru pertama kali melakukan dan mencoba permainan tenis lapangan, sehingga dengan hanya diberikan waktu 16 kali pertemuan atau \pm 4 bulan, tidak dapat mencapai tujuan dari perkuliahan tersebut.

\section{METODE}

Model pengembangan yang digunakan menggunakan model Research and Development $(R \& D)$ dengan menggunakan model pengembangan untuk multimedia yang dikembangkan oleh (Lee \& Owens, 2004). Teknik analisis data yang digunakan pada penelitian ini menggunakan analisis statistik deskriptif. Teknik pengukuran yang digunakan pada pengumpulan data adalah menggunakan skala Likert. Skala Likert digunakan untuk mengukur sikap, pendapat, dan persepsi seseorang atau kelompok orang tentang fenomena sosial (Sugiyono, 2013). Evaluasi ahli dilakukan oleh empat orang ahli, yaitu satu orang ahli media satu orang ahli pembelajaran, satu orang ahli materi di bidang tenis lapangan, dan satu orang ahli evaluasi. Evaluasi ahli disini digunakan sebagai pemberi saran untuk menyempurnakan produk yang dikembangkan.

Instrumen pengumpulan data yang digunakan di dalam penelitian dan pengembangan ini, menggunakan angket untuk mendapatkan data dari subjek ahli, meliputi ahli media, ahli pembelajaran, ahli media, ahli evaluasi, dan data uji coba. Bentuk angket setiap ahli berbeda untuk mengumpulkan data tentang evaluasi berupa masukan, komentar, kritik dan saran para ahli. Selain itu, instrumen yang sudah divalidasi oleh ahli akan dibagikan kepada mahasiswa dengan berupa angket saat uji coba kelompok kecil dengan 15 mahasiswa. Uji coba kelompok besar dengan total mahasiswa subjek uji coba 45 mahasiswa yang mengambil matakuliah tenis lapangan. Pengambilan subjek penelitian ini dilakukan dengan metode random sampling. Rumus 
untuk mengolah data yang berupa analisis deskriptif kuantitatif persentase dan penggolongan persentase pengolahan data (Tabel 1) adalah sebagai berikut (Akbar \& Sriwiyana, 2010).

Keterangan:

$$
V=\frac{T \operatorname{sev}}{\operatorname{Smax}} \times 100 \%
$$

\footnotetext{
$\mathrm{V} \quad=$ Validitas

TSEV = Total Skor Empirik Validator

S-max = Skor maksimal yang diharapkan

$100 \%=$ Konstanta
}

Tabel 1. Penggolongan Persentase Pengolahan Data

\begin{tabular}{cll}
\hline Persentase & \multicolumn{1}{c}{ Kategori } & \multicolumn{1}{c}{ Keterangan } \\
\hline $75,01-100,00 \%$ & Sangat valid & Dapat digunakan tanpa revisi \\
$50,01-75,01 \%$ & Cukup valid & Dapat digunakan dengan revisi kecil \\
$25,01-50,00 \%$ & Tidak valid & Tidak dapat digunakan \\
$00,00-25,00 \%$ & Sangat tidak valid & Terlarang digunakan \\
\hline
\end{tabular}

(Sumber: Akbar \& Sriwiyana, 2010)

Untuk mengetahui efektivitas, efisiensi, dan daya tarik produk yang dikembangkan, instrumen pengumpulan data adalah sebagai berikut.

Pertama, untuk melihat efektivitas produk yang dikembangkan, menggunakan desain rancangan penelitian praeksperimen dalam format “one group pretest - posttest design”, dimana tidak menggunakan kelas pembanding namun sudah menggunakan tes awal sehingga besarnya efek atau pengaruh penggunaan produk yang dikembangkan dapat diketahui secara pasti. Hasil pre-test dan post-test untuk memperoleh data peningkatan hasil belajar dan efektivitas dengan memberikan soal-soal kognitif terkait materi bahan ajar. Penilaian efektivitas dalam penelitian ini hanya sampai kepada penilaian pada aspek kognitif individu pebelajar saja berdasarkan peningkatan pemahaman konsep melalui tes kognitif. Selanjutnya, data dianalisis dengan menggunakan uji liliefors (normalitas) dengan taraf $\alpha=0,05$. Kemudian data dianalisis dengan uji beda dua sampel berpasangan (paired t-test). Paired t-test bertujuan untuk mengkaji pengujian hipotesis dimana data yang digunakan tidak bebas (berpasangan). Walaupun menggunakan individu yang sama, peneliti tetap mendapatkan dua macam data sampel, yaitu data dari perlakuan pertama dan data dari perlakuan kedua (Montolalu \& Langi, 2018). Untuk mengkaji keefektifan produk yang dikembangkan ditandai adanya perbedaan rata-rata sebelum $\left(X_{1}\right)$ dan sesudah $\left(X_{2}\right)$ diberikan produk yang dikembangkan. Untuk menguji ada atau tidaknya perbedaan dua rata-rata sampel digunakan rumus sebagai berikut.

Keterangan:

$t=$ Nilai $T_{\text {hitung }}$

$S D=$ Standar deviasi selisih antara setiap pasangan

$\left(\mathrm{X}_{1}-\mathrm{X}_{2}\right)$

$$
t=\frac{D}{\frac{S D}{\sqrt{n}}}
$$

$D=$ Rata-rata selisih antara setiap pasangan $\left(\mathrm{X}_{1}-\mathrm{X}_{2}\right)$

$n=$ Jumlah Sampel

$d f=\mathrm{N}-1$

Kedua, efisiensi pemanfaatan produk yang dikembangkan dilihat berdasarkan waktu lamanya pembelajaran yang dilakukan hingga tuntas. Berdasarkan pengujian tersebut akan diperoleh rasio dari perbandingan waktu yang diperlukan (berdasarkan waktu yang disediakan berdasarkan perencanaan pembelajaran) dengan waktu yang digunakan oleh pebelajar. Jika rasio waktu yang dipergunakan > 1, maka pembelajaran dikatakan efisiensinya tinggi, begitu juga sebaliknya. Degeng (1998) jika waktu yang dipergunakan lebih kecil dari waktu yang diperlukan maka rasio lebih dari 1, artinya pembelajaran berhasil lebih cepat. Adapun persamaan yang digunakan dalam pengukuran efisiensi adalah sebagai berikut:

$$
\text { Efisiensi Pembelajaran }=\frac{\sum \text { Waktu yang diperlukan }}{\sum \text { Waktu yang digunakan }}
$$

Ketiga, Indikator daya tarik diambil dari sebaran angket uji coba kelompok besar dengan indikator kemenarikan dan kemudahan. Penilaian kemudian dilakukan dari jumlah skor yang diperoleh masing-masing responden dibagi dengan jumlah total skor dan dikalikan dengan banyaknya pilihan jawaban. Skor penilaian tersebut dapat diperoleh dengan menggunakan persamaan sebagai berikut: 


$$
\text { Skor Penilaian }=\frac{\Sigma \text { Skor yang diperoleh responden }}{\sum \text { total skor }} \times 4
$$

Hasil dari rerata skor penilaian tersebut kemudian dikonversikan dalam bentuk pernyataan penilaian untuk menentukan kualitas dan tingkat kemanfaatan produk yang dihasilkan berdasarkan pendapat responden sehingga dapat ditarik sebuah kesimpulan. Jika skor tertinggi menurut pilihan jawaban adalah 4 dan skor terendahnya adalah 1 serta jumlah pilihan jawaban adalah 4, maka didapatkan nilai intervalnya sebagai berikut:

$$
\text { Nilai Interval }=\frac{4-1}{4}=0,75
$$

Kualitas daya tarik berdasarkan indikator dengan nilai interval melalui konversi skor menjadi pernyataan penilaian dapat dilihat pada tabel 2 .

Tabel 2. Konversi Skor Penilaian

\begin{tabular}{ccc}
\hline Skor Penilaian & Rerata Skor & Klasifikasi \\
\hline 4 & $3,26-4,00$ & Sangat Menarik \\
3 & $2,51-3.25$ & Menarik \\
2 & $1,76-2.50$ & Kurang Menari \\
1 & $1,00-1,75$ & Tidak Menarik \\
\hline
\end{tabular}

(Sumber: Prihandono, 2018)

HASIL

Hasil validasi oleh ahli media, ahli pembelajaran, ahli materi, dan ahli evaluasi dijelaskan sebagai berikut. Ringkasan data hasil validasi ahli media terhadap produk yang dikembangkan disajikan pada tabel 3 .

Tabel 3. Hasil Validasi oleh Ahli Media

\begin{tabular}{clcl}
\hline No & \multicolumn{1}{c}{ Indikator } & Persentase (\%) & Keterangan \\
\hline 1 & Teks & $93,75 \%$ & Sangat Valid \\
2 & Gambar/Foto & $100 \%$ & Sangat Valid \\
3 & Audio/Suara & $95 \%$ & Sangat Valid \\
4 & Video & $91,67 \%$ & Sangat Valid \\
5 & Design/Tampilan & $100 \%$ & Sangat Valid \\
\hline & Rata-rata & $96,08 \%$ & Sangat Valid \\
\hline
\end{tabular}

Berdasarkan tabel 3 dapat dilihat bahwa rata-rata persentasae kelayakan produk yang dikembangkan sebesar 96,08 \% artinya menurut validasi media bahwa produk yang dikembangkan sangat valid dan dapat digunakan tanpa revisi. Ringkasan data hasil validasi ahli pembelajaran terhadap produk yang dikembangkan disajikan pada tabel 4.

Tabel 4. Hasil Validasi oleh Ahli Pembelajaran

\begin{tabular}{clcl}
\hline No & Indikator & Persentase (\%) & Keterangan \\
\hline 1 & Kejelasan & $91,18 \%$ & Sangat Valid \\
2 & Ketepatan & $100 \%$ & Sangat Valid \\
3 & Kesesuaian & $91,67 \%$ & Sangat Valid \\
4 & Kemudahan & $100 \%$ & Sangat Valid \\
5 & Kemenarikan & $92,86 \%$ & Sangat Valid \\
\hline & Rata-rata & $95,14 \%$ & Sangat Valid \\
\hline
\end{tabular}

Berdasarkan data pada tabel 4 dapat dilihat bahwa rata-rata persentase kelayakan produk yang dikembangkan sebesar 95,14\% artinya menurut validasi pembelajaran bahwa produk yang dikembangkan sangat valid dan dapat digunakan dengan tanpa revisi. Ringkasan data hasil validasi ahli materi terhadap produk yang dikembangkan disajikan pada tabel 5 . 
Tabel 5. Hasil Validasi oleh Ahli Materi

\begin{tabular}{clll}
\hline No & Indikator & Persentase (\%) & Keterangan \\
\hline 1 & Kejelasan & $83,33 \%$ & Sangat Valid \\
2 & Ketepatan & $93,75 \%$ & Sangat Valid \\
3 & Kesesuaian & $87,5 \%$ & Sangat Valid \\
4 & Kemudahan & $75 \%$ & Cukup Valid \\
\hline & Rata-rata & $84,03 \%$ & Sangat Valid \\
\hline
\end{tabular}

Berdasarkan data pada tabel 5 dapat dilihat bahwa rata-rata persentasae kelayakan produk yang dikembangkan sebesar $84,03 \%$ artinya menurut validasi materi bahwa produk yang dikembangkan sangat valid dan dapat digunakan dengan tanpa revisi. Ringkasan data hasil validasi ahli evaluasi terhadap produk yang dikembangkan disajikan pada tabel 6.

Tabel 6. Hasil Validasi oleh Ahli Evaluasi

\begin{tabular}{ccll}
\hline No & Materi & Persentase & Keterangan \\
\hline 1 & 1 & $72,3 \%$ & Cukup Valid \\
2 & 2 & $74,3 \%$ & Cukup Valid \\
3 & 3 & $74,67 \%$ & Cukup Valid \\
\hline & Rata-rata & $73,8 \%$ & Cukup Valid \\
\hline
\end{tabular}

Berdasarkan data pada tabel 6 dapat dilihat bahwa rata-rata persentasae kelayakan produk yang dikembangkan sebesar 73,8 \% artinya menurut validasi evaluasi bahwa produk yang dikembangkan cukup valid dan dapat digunakan dengan revisi kecil. Ringkasan hasil uji coba kelompok kecil dan kelompok besar disajikan pada tabel 7.

Tabel 7. Hasil Persentase Uji Coba Kelompok Kecil

\begin{tabular}{clc}
\hline No Butir & Aspek & Persentase \\
\hline 1 & Kemenarikan & $90 \%$ \\
2 & Kemudahan & $90 \%$ \\
3 & Kejelasan & $93,9 \%$ \\
4 & Kelayakan & $87,5 \%$ \\
5 & Ketepatan & 91,67 \\
\hline & Rata-rata & $90,6 \%$ \\
\hline
\end{tabular}

Berdasarkan data pada tabel 7 uji coba kelompok kecil di atas menunjukkan hasil 90,6\% dan masuk kategori sangat valid. Semua kriteria telah memenuhi kelayakan produk sehingga produk yang dikembangakan dinyatakan sudah baik dan layak digunakan serta dapat dilanjutkan ke uji coba kelompok besar. Ringkasan hasil uji coba kelompok kecil dan kelompok besar disajikan pada tabel 8 .

Tabel 8. Hasil Persentase Uji Coba Kelompok Besar

\begin{tabular}{clr}
\hline No Butir & Aspek & Persentase \\
\hline 1 & Kemenarikan & $95,1 \%$ \\
2 & Kemudahan & $92,2 \%$ \\
3 & Kejelasan & $93,9 \%$ \\
4 & Kelayakan & $95 \%$ \\
5 & Ketepatan & $94,1 \%$ \\
\hline & Rata-rata & $93,6 \%$ \\
\hline
\end{tabular}

Berdasarkan tabel 8, uji coba kelompok besar di atas menunjukkan hasil 93,6\% dan masuk kategori sangat valid. Semua kriteria telah memenuhi kelayakan produk sehingga produk yang dikembangkan dapat dijadikan media pembelajaran dan sumber belajar alternatif bagi mahasiswa khususnya dan masyarakat luas pada umumnya.

\section{Efektivitas, Efisiensi, dan Daya Tarik Produk yang Dikembangkan}

Hasil analisis efektivitas, efisiensi, dan daya tarik terhadap produk yang dikembangkan dijelaskan sebagai berikut. Ringkasan data hasil analisis efektivitas terhadap produk yang dikembangkan disajikan pada tabel 9. 
Tabel 9. Hasil Perhitungan Uji Normalitas

\begin{tabular}{ccc}
\hline Keterangan & Lhitung & Ltabel \\
\hline Pre-test & 0,043 & 0,132 \\
Post-test & 0,015 & 0,132 \\
\hline
\end{tabular}

Dari hasil perhitungan uji normalitas pada tabel 9 diperoleh data pre-test dan post-test dengan data pre-test harga $\mathrm{L}_{\text {hitung }}$ $0,043 \leq \mathrm{L}_{\text {tabel }} 0,132$, maka data pre-test berasal dari distribusi normal. Data post-test harga $\mathrm{L}_{\text {hitung }} 0,015 \leq \mathrm{L}_{\text {tabel }} 0,132$ dan posttest $0,076 \leq 0,132$, maka data post-test berasal dari distribusi normal dengan taraf signifikan $\alpha=0,05$. Dengan demikian, dapat peneliti simpulkan bahwa data pre-test dan post-test berasal dari populasi yang berdistribusi normal. Kemudian dilakukan uji beda dengan menggunakan metode paired t-test terhadap produk yang dikembangkan.

Tabel 10. Hasil Perhitungan Uji Beda (Paired t-test)

\begin{tabular}{cccc}
\hline Keterangan & Rata-rata $(\boldsymbol{x})$ & $\boldsymbol{T}_{\text {hitung }}$ & $\boldsymbol{T}_{\text {tabel }}$ \\
\hline Pre-test & 64 & 6,708 & 2,015 \\
Post-test & 80 & & \\
\hline
\end{tabular}

Dari hasil uji beda menggunakan paired t-test (lihat tabel 10) didapatkan hasil antara pre-test dan post-test diperoleh $\boldsymbol{T}_{\text {hitung }}=6,708 \geq T_{\text {tabel }}=2,015$, maka terdapat perbedaan secara signifikan antara data pre-test dan post-test dan $\mathrm{H}_{0}$ ditolak. Sehingga dapat disimpulkan nilai rata-rata sebelum menggunakan produk $\neq$ nilai rata-rata setelah menggunakan produk yang dikembangkan. Kemudian dari data perhitungan tersebut, diperoleh rata-rata pre-test $\left(X_{1}\right)=64 \leq$ rata-rata post-test $\left(X_{2}\right)=80$. Dengan demikian, dapat dinyatakan bahwa produk yang dikembangkan efektif terhadap hasil belajar karena terdapat perubahan kenaikan skor sebelum dan sesudah menggunakan produk yang dikembangkan.

Ringkasan data hasil analisis efisiensi terhadap produk yang dikembangkan dilakukan dengan cara melihat waktu pembelajaran hingga mencapai ketuntasan pebelajar dalam mempelajari seluruh materi. Penentuan efisiensi pada waktu yang diperlukan adalah 90 menit. Penentuan efisiensi pada waktu yang digunakan didapatkan dari rata-rata penyelesaian waktu mengerjakan soal adalah 50 menit.

$$
\begin{gathered}
\text { Efisiensi Pembelajaran }=\frac{\sum \text { Waktu yang diperlukan }}{\sum \text { Waktu yang digunakan }} \\
\text { Efisiensi Pembelajaran }=\frac{90}{50} \\
\text { Efisiensi Pembelajaran }=1,80
\end{gathered}
$$

Berdasarkan nilai rata-rata rasio yang diperoleh adalah 1,80 hal itu menunjukan bahwa efisiensinya tinggi, karena rasio yang didapatkan lebih dari 1. Dengan demikian, dapat disimpulkan bahwa penggunaan produk yang dikembangkan dapat meningkatkan efisiensi dalam waktu pembelajaran.

Ringkasan data hasil analisis daya tarik terhadap produk yang dikembangkan dilakukan dengan melihat hasil penilaian pada indikator kemenarikan dan kemudahan pada saat uji coba kelompok besar terhadap produk yang dikembangkan. Hasil analisis pada indikator tersebut diperoleh rata-rata 93,63\%. Selanjutnya, penilaian tersebut dikonversikan dalam bentuk pernyataan penilaian untuk menentukan kualitas dan tingkat kebermanfaatan produk yang dihasilkan berdasarkan pendapat responden sehingga dapat ditarik sebuah kesimpulan. Kualitas daya tarik berdasarkan indikator dengan rentang data melalui konversi skor menjadi pernyataan penilaian, dengan rumus:

$$
\begin{gathered}
\text { Skor Penilaian }=\frac{\sum \text { Skor yang diperoleh responden }}{\Sigma \text { total skor }} \times 4 \\
\text { Skor Penilaian }=\frac{3039}{3240} \times 4 \\
\text { Skor Penilaian }=3,75
\end{gathered}
$$

Selanjutnya, rerata skor penilaian didapatkan adalah 3,75 dan setelah dikonversikan (lihat tabel 2) termasuk kedalam kriteria sangat menarik, dari hasil tersebut dapat disimpulkan bahwa hasil pengembangan bahan ajar tenis lapangan dalam bentuk multimedia interaktif ini dapat menarik minat mahasiswa untuk belajar. 


\section{PEMBAHASAN}

Produk dalam penelitian pengembangan ini adalah berupa bahan ajar tenis lapangan dalam bentuk multimedia interaktif untuk mahasiswa. Produk ini disajikan dalam bentuk multimedia interaktif yang dikemas dalam bentuk DVD (Digital Versatile Disc). Produk bahan ajar tenis lapangan dalam bentuk multimedia interaktif ini berupa materi-materi tenis lapangan yang tediri (1) sejarah tenis lapangan; (2) sarana dan prasarana; (3) teknik-teknik dasar tenis lapangan; (4) peraturan dan perwasitan tenis lapangan; (4) video tutorial cara pengisian score sheets; (5) rule of tennis, yang berisikan contoh kasus atau masalah yang terjadi dalam pertandingan resmi serta cara menyelesaikannya sesuai dengan peraturan yang ada.

Keunggulan dari bahan ajar ini adalah adanya berbagai macam jenis media, seperti audio, video, animasi, dan teks. Peneliti sependapat dengan pernyataan Smaldino et al (2011) bahan ajar dibuat bertujuan untuk memudahkan belajar secara mandiri dan bahan ajar tersebut dibentuk menjadi sekumpulan materi cetakan, audiovisual, atau yang berbasis komputer (ataupun kombinasi apapun dari itu). Hal senada juga diutarakan oleh (Barnard et al., 2009) untuk membantu menjelaskan konsep gagasan dan membantu memotivasi peserta belajar aktif adalah dengan melibatkan multimedia (komputer, laptop dan tablet). Perpaduan antara media dan strategi pembelajaran yang sesuai juga diyakini banyak pihak akan mampu meningkatkan dorongan pebelajar untuk belajar. Hal serupa juga serupa dengan pernyataan bahwa pemilihan prosedur yang sesuai dengan melibatkan multimedia akan menarik perhatian pebelajar untuk belajar (Asrika Maha Dewi et al., 2013)

Perkuliahan tenis lapangan memiliki tujuan yang sama pada pembelajaran PJOK di sekolah, yaitu pada aspek kognitif, afektif, dan psikomotor. Akan tetapi, ketiga aspek tersebut tidak dapat dipisahkan mengingat hanya menitikberatkan pada salah satu aspek saja. Hasil dari pembelajaran tenis lapangan memang mengarah pada psikomotorik yaitu lebih menuntut kepada terampil dalam kemampuan gerak tenis lapangan. Oleh sebab itu, untuk menghasilkan psikomotor yang baik diperlukan tahapan pembelajaran mulai dari kognisi, asosiasi, dan otomatisasi. Aspek kognitif menjadi dasar untuk mengembangkan psikomotorik dan pada aspek afektif akan tercipta jika proses aspek psikomotor yang ditunjang aspek kogntif berjalan dengan lancar. Agar proses kognisi tersebut dapat dikembangkan secara maksimal maka salah satu solusinya adalah dengan memanfaatkan teknologi kedalam pembelajaran yaitu dalam bentuk multimedia interaktif yang dilengkapi dengan kuis dan soal latihan. Multimedia interaktif tersebut ditujukan untuk menunjang aspek kognitif yang difungsikan untuk memudahkan, menambah pengetahuan, serta belajar mandiri bagi mahasiswa.

Selain itu, peran multimedia interaktif tersebut dapat meningkatkan minat dan motivasi belajar. Seperti yang diungkapkan oleh (Kavita et al., 2013) penggunaan teknologi komputer dalam pengajaran pendidikan jasmani dapat meningkatkan minat dan motivasi siswa dalam berolahraga dibandingkan pengajaran pendidikan jasmani dengan penggunaan metode tradisional. Produk bahan ajar yang dikembangkan tersebut juga sesuai dengan karakter pebelajar sekarang. Hal tersebut senada yang diungkapkan oleh Palfrey \& Gasser (2008) pebelajar lebih suka bahan ajar visual interaktif karena dikategorikan sebagai penduduk asli digital (digital native), sedangkan pengajar dan orangtua diibaratkan sebagai "pendatang" dalam dunia teknologi digital (digital imigrants). Kedua ahli tersebut menggolongkan kaum pribumi dunia digital sebagai kaum muda yang lahir dan tumbuh pada pertengahan 1980 - 2000. Selanjutnya, kedua pengamat internet dan teknologi dari Harvard Law School ini menyatakan bahwa penduduk asli digital (digital native) menjadi terbiasa mengungkapkan ekspresi mereka melalui berbagai media digital, misalnya telepon selular (melalui suara dan pesan teks singkat), surat elektronik (e-mail), pesan internet (internet messengger), blog dan juga bersosialisasi dengan situs jejaring sosial di dunia maya, seperti friendster, twitter, dan facebook. Manfaat dari bahan ajar tenis lapangan dalam multimedia interaktif tersebut dapat membantu dalam proses transfer informasi yang terjadi dalam pembelajaran secara runtun dan sistematis. Hal itu sesuai dengan yang diungkapkan (Chang et al., 2006) bahan ajar yang diproduksi dengan bantuan penggunaan teknologi (system) akan tampak lebih terpadu dan sistematis, memberikan informasi lebih dalam dan lebih luas untuk belajar.

Interaksi antara pengajar, sumber belajar dan pebelajar dapat lebih efektif salah satunya dengan adanya bahan ajar dalam pembelajaran. Hal serupa juga diungkapkan oleh (Kizilaslan et al., 2012) untuk mencapai target kurikulum yang ditentukan keberadaan bahan ajar berperan penting sebagai sumber informasi yang termudah bagi pebelajar untuk mempraktikkan apa yang ada dalam materi dalam pembelajaran. Peneliti juga sependapat dengan pernyataan (Riyana, 2010) semakin banyaknya pilihan sumber belajar yang tersedia akan membuat proses pembelajaran semakin baik. Bahan ajar dalam bentuk multimedia interaktif tersebut, selain menjadi media belajar juga digunakan sumber belajar untuk merangsang proses pembelajaran yang bersifat abstrak menuju konkret yang dapat diamati secara langsung. Dwiyogo (2013) pebelajar akan lebih mudah mudah mempelajari hal-hal yang bersifat konkret daripada yang berisifat abstrak. Reigeluth (2015) mengemukakan bahwa efektivitas mengacu kepada indikator belajar yang tepat (seperti tingkat prestasi dan kefasihan tertentu) untuk mengukur hasil pembelajaran. Pada konteks ini, efektivitas diukur melalui hasil belajar mahasiswa yang didapat sebelum dan sesudah menggunakan produk yang dikembangkan.

Efisiensi disini adalah penghematan waktu dalam proses pembelajaran terutama kemampuan bahan ajar meminimalisir beban kerja pengajar sebagaimana pada pembelajaran konvensional yang menekankan kepada proses penyampaian materi secara verbal dari seorang pengajar, pebelajar tidak dituntut untuk menemukan materi itu sendiri, serta kemampuan bahan ajar menyediakan materi yang dikemas menarik untuk diakses oleh pebelajar. Ketersedian seluruh rangkaian kegiatan pembelajaran dalam produk yang dikembangkan ini mampu mereduksi kegiatan-kegiatan yang menyebabkan pembelajaran menjadi tidak efisien dan menyediakan materi untuk pebelajar yang selama ini sulit untuk pebelajar mengaksesnya. 
Indikator kemenarikan dan kemudahan pada bahan ajar tenis lapangan dalam bentuk multimedia interaktif menjadi indikator utama yang harus diperhatikan karena indikator kemenarikan dan kemudahan mampu memotivasi pebelajar untuk melakukan pembelajaran atau mengakses materi pembelajaran. Hal ini dapat dilihat bahwa beberapa ahli pendidikan yang mendukung pendekatan yang berpusat pada siswa (student centered) memberikan kriteria ini di atas kriteria lainnya, yaitu efektivitas dan efisiensi. Roblyer \& Hughes (2018) anak-anak memahami dan mengingat konsep-konsep yang lebih baik ketika mereka menemukan konsep diri mereka sendiri melalui eksplorasi. Merujuk pada teori tersebut yang keterlibatannya adalah pebelajar harus didorong untuk belajar sendiri secara mandiri dan diberikan kesempatan untuk berekplorasi secara terstruktur. Produk bahan ajar tenis lapangan ini memungkinkan pebelajar untuk belajar secara mandiri yang melibatkan pebelajar secara aktif dalam menemukan konsep-konsep materi, mendorong pebelajar untuk mencoba dan melakukan secara mandiri terhadap materi yang diakses oleh pebelajar dan membangkitkan rasa ingin tahu pebelajar. Hasil penelitian menunjukkan bahwa memfasilitasi pebelajar untuk belajar secara mandiri dan memberikan kesempatan pebelajar untuk bereksplorasi, efektif meningkatkan prestasi belajar.

\section{SIMPULAN}

Simpulan dari penelitian ini adalah bahwa produk yang dikembangkan yang telah divalidasi oleh beberap ahli yang sesuai di bidang kepakarannya menunjukan hasil akhir dengan kategori cukup baik dengan keterangan dapat digunakan dengan beberapa revisi kecil. Selanjutnya, produk yang telah dikembangkan efektif terhadap hasil belajar karena terdapat perubahan kenaikan skor sebelum dan sesudah menggunakan produk yang dikembangkan. Kemudian produk yang dikembangkan dapat meningkatkan efisiensi dalam waktu pembelajaran serta dapat menarik minat pebelajar untuk belajar.

\section{DAFTAR RUJUKAN}

Akbar, S., \& Sriwiyana, H. (2010). Pengembangan Kurikulum dan Pembelajaran - Ilmu Pengetahuan Sosial (IPS). Jakarta: Cipta Media.

Asrika Maha Dewi, N. P., Dibia, I. K., \& Nyoman Sudana, D. (2013). Pengaruh Model Pembelajaran Problem Based Learning Berbantuan Media Video terhadap Hasil Belajar IPA Kelas IV SD Negeri Pergung. Mimbar PGSD UNDIKSHA Universitas Pendidikan Ganesha, 1(1).

Barnard, L., Lan, W. Y., To, Y. M., Paton, V. O., \& Lai, S. L. (2009). Measuring Self-Regulation in Online and Blended Learning Environments. Internet and Higher Education, 12(1), 1-6. https://doi.org/10.1016/j.iheduc.2008.10.005

Chang, K. E., Sung, Y. T., \& Hou, H. T. (2006). Web-based Tools for Designing and Developing Teaching Materials for Integration of Information Technology Into Instruction. Educational Technology and Society, 9(4), $139-149$.

Dwikat, B., Joudallah, H., \& Khader, W. (2018). The Effect of using one of the Multimedia in Developing Teaching Skills for Practical Education Studentsin Faculty of Sport Eduation. IOSR Journal of Sports and Physical Education (IOS-JSPE), 5(2), 10-14. https://doi.org/10.9790/6737-05021014

Dwiyogo, W. (2014). Analisis Kebutuhan Pengembangan Model Rancangan Pembelajaran Berbasis Blended Learning (PBBL) untuk Meningkatkan Hasil Belajar Pemecahan Masalah. Jurnal Pendidikan dan Pembelajaran (JPP), 21(1), 71-78.

Juniu, S. (2011). Pedagogical Uses of Technology in Physical Education. Journal of Physical Education, Recreation \& Dance, 82(9), 41-49. https://doi.org/10.1080/07303084.2011.10598692

Kavita, V., Sharma, J. P., \& Tiwari, R. K. (2013). Use of Information Technology in Physical Education and Sport. International Journal in Multidisciplinary and Academic Research (SSIJMAR), 2(4), 2278-5973. http://ssijmar.in/vol2no4/vol2 no4.5.pdf

Kizilaslan, A., Sözbilir, M., \& Diyaddin Yaşar, M. (2012). Inquiry based teaching in Turkey: A Content Analysis of Research Reports. International Journal of Environmental and Science Education, 7(4), 599-617.

Lee, W. W., \& Owens, D. L. (2004). Multimedia-Based Instructional Design (Second Edi). Pfeiffer.

Montolalu, C., \& Langi, Y. (2018). Pengaruh Pelatihan Dasar Komputer dan Teknologi Informasi bagi Guru-Guru dengan UjiT Berpasangan (Paired Sample T-Test). Jurnal Matematika dan Aplikasi DeCartesian, 7(1), 44-46. https://doi.org/10.35799/dc.7.1.2018.20113

Nurdyansyah., \& Fahyuni, E. F. (2016). Inovasi Model Pembelajaran. Nizamia Learning Center.

Palfrey, J., \& Gasser, U. (2008). Born Digital: Understanding The First Generation of Digital Nativer. Basic Books.

Pluim, B. M., Staal, J. B., Marks, B. L., Miller, S., \& Miley, D. (2007). Health benefits of tennis. British Journal of Sports Medicine, 41(11), 760-768. https://doi.org/10.1136/bjsm.2006.034967

Prihandono, E. (2018). LKM Berbasis Inkuiri Terbimbing untuk Meningkatkan Keterampilan Proses Sains. Jurnal Pendidikan Fisika, VI(2), 209-222.

Reigeluth, C. M. (2015). Instructional Theory and Technology for the New Paradigm of Education. RED. Revista de Education a Distancia, 181-196. https://doi.org/10.4324/9781315760933

Riyana, C. (2010). Peningakatan Kompetensi Pedagogis Guru melalui Penerapan Model Education Centre of Teacher Interactive Virtual (Educative). Jurnal Penelitian Pendidikan, 11(1), 40-48.

Roblyer, M. D., \& Hughes, J. E. (2018). Integrating Educational Technology Into Teaching : Transforming Learning Across Disciplines. 576. 
Smaldino, S. E., Lowther, D. L., \& Mims, C. (2011). Instructional Technology and Media for Learning. Sugiyono. (2013). Metode Penelitian Pendidikan (Pendekatan Kuantitatif, Kualitatif dan R\&D). Alfabeta.

Teoh, B., \& Neo, T.-K. (2007). Interactive Multimedia Learning: Students' Attitudes and Learning Impact in an Animation Course. Online Submission, 6(4).

Xavier, F., \& Francis, M. (2017). Use of Multimedia ( ICT ) as a Educational Tool in High School Education- A Study. Amity Journal of Media \& Communication Studies, 7(1), 31-37. 